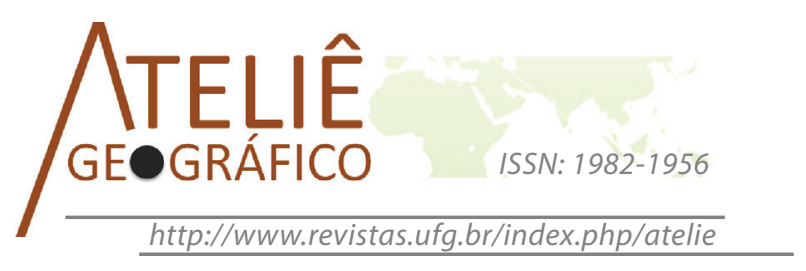

\title{
Queensland Parks as Environmental Learning Settings: Visitors, Guiding, and Environmental Interpretation in Australia
}

\author{
Parques em Queensland como Locais de Aprendizado \\ Ambiental: Visitantes, Guiamento, e Interpretação na \\ Austrália
}

\section{Parques en Queensland como Sitios para el Aprendizaje Ambiental: Visitantes, Guías, e Interpretación Ambiental en Australia}

\author{
Ismar Borges de Lima \\ Southern Cross University, Australia \\ Universidade Estadual de Roraima, Brasil \\ ismarlima@yahoo.com.br
}

\begin{abstract}
The main goal of this article is to conceptually discuss how important guiding and environmental interpretation is for enhancing the visitors experiences and for conservation in national parks. Tour guides and Park rangers have played a bridging role for connecting visitors to nature; they have an important mediation role in wildlife and nature encounters. Desktop research for this study includes literature review, technical visits to parks, and interviews with key informants. This article is predominantly qualitative. It contributes to the literature at identifying the main aspects, natural and educational resources, and attractions of the Parks in Queensland, with an emphasis on the Springbrook National Park. The major educational programs in the Gold Coast region and the tools used for environmental interpretation, including the role of guides and rangers, are comprehensively discussed. The outcomes show that the Parks have served to these educational means, but environmental interpretation and education should be expanded to accommodate in large numbers the general visitors - others than the school visitors. Other major challenges are related to lack of proper fund allocations for environmental education programmes and to the workloads of rangers.
\end{abstract}

Keywords: Environmental interpretation; educational and recreational activities; guiding; National parks; visitor management. 


\begin{abstract}
Resumo
O principal objetivo deste artigo é discutir conceitualmente a importância da interpretação ambiental para se melhorar as experiências dos visitantes e para a conservação ambiental em parques nacionais. Nesse sentido, guias de turismo e guardas-florestais têm desempenhado um papel crucial servindo de elo entre visitantes e o meio ambiente local; eles têm um papel importante ao mediar os encontros entre os visitantes e a vida selvagem e flora. Como parte da pesquisa foi feita a revisão de literatura, visitas técnicas a parques, e entrevistas com informanteschave. Este artigo é predominantemente qualitativo. O artigo contribui para a literatura ao identificar os principais aspectos, recursos naturais e educacionais, bem como as atrações dos parques em Queensland, com destaque para o Parque Nacional Springbrook. Os principais programas educacionais na região de Gold Coast e as ferramentas utilizadas para a interpretação ambiental, incluindo o papel dos guias e dos guardas florestais, são amplamente discutidos. Os resultados revelam que os parques têm servido para estes fins educativos, mas a interpretação e educação ambiental deve ser expandida a fim de acomodar em maior número visitantes que nao fazem parte dos grupos de escola. Além disso, outros desafios estão relacionados à falta de alocação de fundos adequados para programas de educação ambiental e à carga de trabalho dos guardas-florestais.
\end{abstract}

Palavras-chave: Interpretação ambiental; atividades educativas e recreativas; guiamento; parques nacionais; gestão de visitantes.

\begin{abstract}
Resumen
El propósito principal de este artículo es conceptualmente discutir la importancia de la interpretación ambiental para mejorar las experiencias de los visitantes y para la conservación ambiental en parques nacionales. Así, guías de turismo y guardabosques han tenido un papel crucial que sirve de enlace entre los visitantes y el medio ambiente local; ellos tienen un papel importante para mediar los encuentros entre los visitantes, la fauna y la flora. Como parte de la investigación se llevó a cabo la revisión de la literatura, visitas técnicas a parques, y entrevistas con informantes clave. Este artículo es predominantemente cualitativo. El documento contribuye para la literatura, pues busca identificar los aspectos principales, los recursos naturales y educativos, así como las atracciones de los parques de Queensland, en especial el Parque Nacional de Springbrook. Los principales programas educativos de la región de Gold Coast y las herramientas utilizadas para la interpretación ambiental, incluyendo el papel de guías y de los guardabosques, son ampliamente debatidos. Los resultados muestran que los parques han servido para estos fines educativos, pero la interpretación y educación ambiental deben ser ampliadas para dar cabida a un mayor número de visitantes que no forman parte de los grupos escolares. Además, otros desafíos se relacionan con la falta de asignación de fondos suficientes para los programas de educación ambiental y la carga de trabajo de los guardaparques.
\end{abstract}

Palabras clave: Interpretación ambiental; actividades educativas y recreativas; guías; parques nacionales; gestión de visitantes.

\title{
Introduction
}

Australia has over 9,000 protected areas which cover roughly 95 million hectares, an extension of land which rewards the country with significant land-mass protection, totalling 11 percent of its whole territory (TTF, 2013). The term 'park' has different 
definitions and understandings; it varies institutionally and geographically as one takes into account its multiple uses and, or, its status as a protected land. For example, a natural area known as a 'park' in one place may be considered as a recreational area in another. A historical record shows that a park has been "diverse things as a place to bathe, a hunting preserve, a formal garden... a common space for tethering livestock prior to bartering... in some countries, a place for exercising, walking, and nature viewing" (LANKFORD, KNOWLES-LANKFORD, \& WHEELER, 2011, p.4). In this study, attention is given to 'nature parks' with significant land extension for conservation and amenities for recreation, leisure, enjoyment, contemplation, and learning. Amusement and theme parks are not part of this investigation.

The main goal of this article is to conceptually discuss how important environmental interpretation and guiding is for enhancing the visitors' experiences in Queensland Parks. The term 'visitor' in this article refers to a local, interstate, or foreign person - or group of people - visiting, enjoying, and experiencing the parks and natural settings for different motivations and interests; this includes the local school groups joining curriculum-based activities in the Parks. As part of the qualitative analysis, the main aspects, resources, and attractions of the Springbrook National Park are presented. Desktop research for this study includes literature review, technical visits to parks, and interviews with key informants. This article is predominantly qualitative. It contributes to the literature at identifying the main aspects, natural and educational resources, and attractions of the Parks in Queensland, with an emphasis on the Springbrook National Park. The major educational programs and tools for environmental interpretation, including the role of guides and rangers, are also comprehensively discussed in the article. Are the National Parks serving as natural settings for environmental interpretation and education of the visitors in Queensland?

In Australia, seven major categories of protected areas under the IUCN Reserve Types are presented in the National Reserve System (NRS): Strict Nature Reserve (IA), Wilderness Area (IB), National Park (II), Natural Monument (III), Habitat/Species Management Area (IV), Protected Landscape/Seascape (V), and Managed Resource Protected Area (VI). Under the NRS, there are 1,086 National Parks registered covering an area of 38,053,578 hectares (Department of the Environment, Australian Government, online, 2015). According to the Department of the Environment - Australian Government, Queensland has 1,086 protected areas corresponding to 8.16 percent of its state land. The Australian Capital Territory has only 46 protected areas but they correspond to 55.22 percent of its overall land. Tasmania has 1,524 protected areas covering 44.09 percent of its territory. Figure 1.0 shows the number of protected areas in the country and the corresponding percentages in each Territory. According to the Department of Environment of the Australian Government, the vast majority of land belonging to the NRS is open for public access, and visits are controlled by management plans aiming to minimise the negative impacts and disturbances to sensitive fauna and flora. Access and use restrictions also apply to Indigenous/Aboriginal sacred sites in respect to ethnic and cultural issues. 


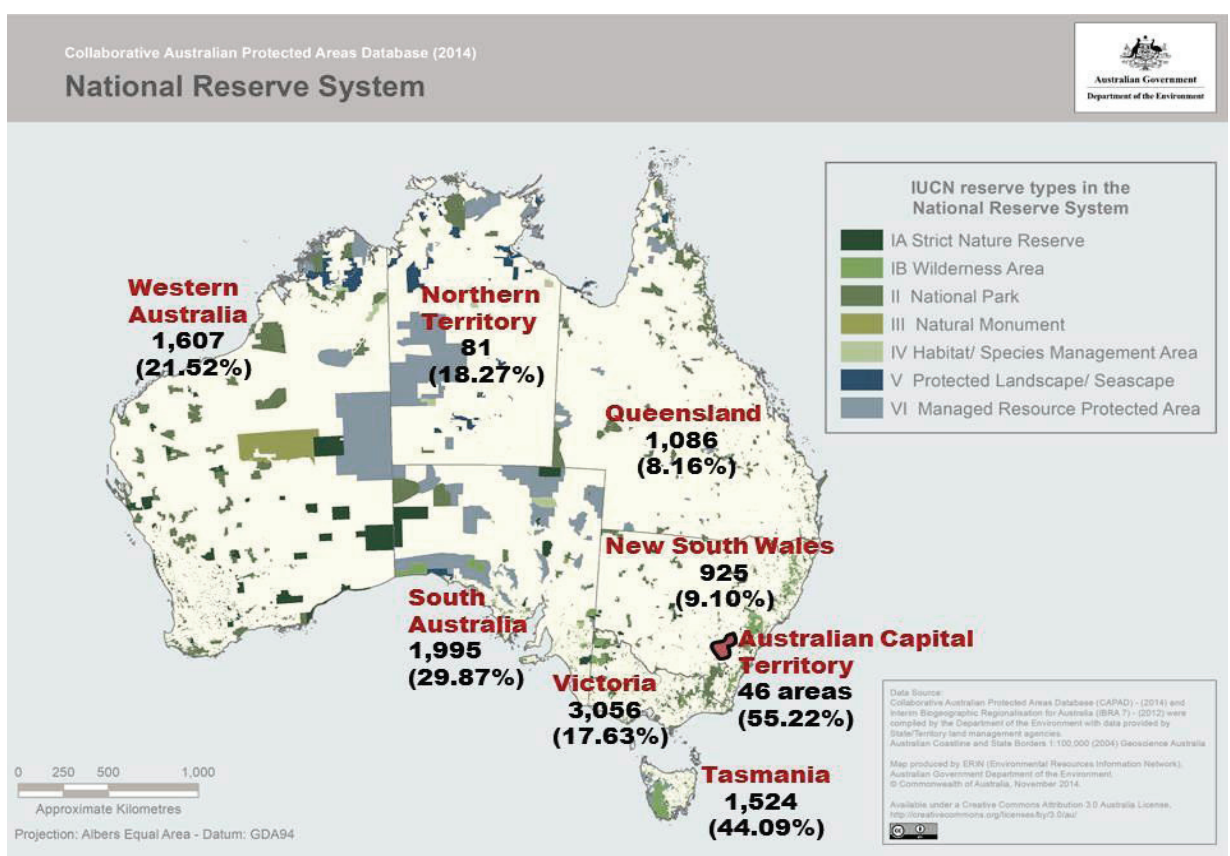

Figure 1.0 - Australian protected areas for each territory and the types of reserves in the NRS.

Source: This map was adapted from the Collaborative Australian Protected Areas Database (2014),

Department of Environment, Australian Government. The original image was produced by ERIN

(Environmental Resources Information Network), and is available under a Creative Commons Attribution 3.0 Australia License, November 2014.

In addition to government protected land, there is also private land under the status of protected areas totalling 1,223 units covering one percent of Australia. In general, this type of property belongs to private landholders, community groups, organisations, trustees. Most of them are open for the public and have a pivotal role in protecting biodiversity in peri-urban or rural areas; they also run volunteer programs, and some properties offer walking trails and campground facilities to host independent visitors and tour groups (Department of the Environment, Australian Government, online, 2015).

According to Victoria Parks' website, the categories of parks in that specific State is: National parks, state park, wilderness park, regional park, marine national parks, marine sanctuaries, and coastal parks, and metropolitan parks. The latter refers to an area managed for intensive recreation and conservation if applicable. In Queensland, the National Parks lie in six different sub-categories; National Park (Scientific), National Park, National Park (Aboriginal Land), National Park (Torres Strait Islander Land), National Park (Cape York Peninsula Aboriginal Land), and National Park (Recovery). Table 1.0 shows the current situation of protected areas in Queensland, including the National Parks, as of 2012. 
Table 1.0 - Situation of Protected Areas in Queensland as in 2012.

\begin{tabular}{|c|c|c|c|}
\hline National Park Type & Number & Area (ha) & $\begin{array}{l}\% \text { of } \\
\text { Qld }\end{array}$ \\
\hline National Park (Scientific) & 9 & 53,189 & \\
\hline National Park & 279 & $6,911,089$ & \\
\hline National Park (Aboriginal Land) & 0 & 0 & \\
\hline National Park (Torres Strait Islander Land) & 0 & 0 & \\
\hline National Park (Cape York Peninsula Aboriginal Land) & 12 & $1,253,500$ & \\
\hline National Park (Recovery) & 20 & 37,231 & \\
\hline Total national parks in Queensland (Qld) & 320 & $8,255,008$ & $4.77 \%$ \\
\hline Tenured Protected Areas (Public Land) & Number & Area (ha) & $\begin{array}{l}\% \text { of } \\
\text { Qld }\end{array}$ \\
\hline Total National Parks & 320 & $8,255,008$ & \\
\hline Conservation Parks & 224 & 68,232 & \\
\hline Resources Reserves & 44 & 341,564 & \\
\hline Forest Reserves & 99 & 192,698 & \\
\hline Total tenured protected areas in Queensland & 687 & $8,857,503$ & $5.12 \%$ \\
\hline Non-tenured Protected Areas & Number & Area (ha) & $\begin{array}{l}\text { \% of } \\
\text { Qld }\end{array}$ \\
\hline Nature refuges & 411 & $2,914,222$ & \\
\hline Coordinated Conservation Areas & 2 & 2,121 & \\
\hline Total non-tenured protected areas in Qld & 413 & $2,916,343$ & \\
\hline TOTAL PROTECTED AREAS IN QLD & 1,100 & $11,773,847$ & $6.80 \%$ \\
\hline
\end{tabular}

Source: This Table was presented by Des Boyland, Secretary to the State Council, during the Wildlife Queensland`s Brisbane North Branch Seminar, on 11 November 2012. Available online at, http://www. wildlife.org.au/conservation/issues/2012/image/thefutureofprotectedareas.pdf

National Park is one of the categories as a protected area, and there are 1,086 National Parks registered in the country according to the Australian Nature Reserve System, NRS (Department of Environment, Australian Government, online, 2015). A National Park is described by the IUCN (1994) as:

A natural area of land/or sea, designated to (a) protect the ecological integrity of one or more ecosystems for present and future generations, (b) exclude exploitation or occupation inimical to the purposes of designation of the area, and (c) provide a foundation for the spiritual, educational, recreational and visitor opportunities, all of which must be environmentally and culturally compatible (p. 19).

But, what are the motivations for visiting a nature park? Kern (2006) identified in the existing literature the major factors which contribute to the demands for visitation to Australian national parks and other protected areas in the country: an increasing in the urban population in Australia which make people look for evasion and (re)encounter with nature; a growing interest for adventure activities and recreation; "the Australian natural 
landscape and heritage are major drawcards particularly for international visitors"; "marketing campaigns that promote protected areas as tourism destinations"; "World Heritage (WH) status as a magnet for tourists" (p. 3).

With regards to environmental interpretation and conservation in Australian Parks, early works can be found in the 1990s as Beckmann (1991) developed research on environmental interpretation for education and management in Australian National Parks and Protected Areas. In 1996, Bolwell contributed to the literature with an overview of interpretation in National Parks Agencies in Australia. In 1999, the Department of Natural Resources and Environment Victoria released a technical report entitled, 'Best practice in Park interpretation and education'. Other early works on the relevance of environmental interpretation in the Australian Parks were published by Moscardo (2002), Armstrong and Weiler (2003), Madin and Fenton (2004), and Hughes and Morrison (2005). A review in the literature also reveals that 'zoning' and 'overlays' are central management tools and frameworks for defining multiple use areas within a park. For example, 'recreation zones' can be established to provide facilities and amenities for human leisure and enjoyment such as picnic areas and campsites. Conservation zones are usually land allocated for protecting the natural and cultural settings and resources (GERLACH, 2008). The conceptual debate on Parks would not be complete without few words about their intrinsic environmental and aesthetic values. The intrinsic value can be a criterion for a moral standing in our society, the timeless value of a standing tree in the forest; it has to do with the invisible benefits the Parks bring which go beyond one's perception and admiration of the greenery, the fresh inviting streams and lakes, the emotions of an encounter with a huge waterfall, and the pleasing walks under the shadows.

\section{The intrinsic and functional values of nature in protected areas: a brief conceptual discussion}

In our society, it is possible to assert that the utilitarian values of nature seem to overlap the intrinsic ones with the prevalence of an anthropocentric paradigm. What are the intrinsic and functional values of protected areas? What is the value of a standing forest? What can be said about an 'ecological ethics'? How do people perceive nature and ecological conservation? Nature is what humans say it is, and becomes what humans make of it. Rolston (1998) argues that values are objective in nature, and underlines that "any object, whatever it may be, acquires value when any interest, whatever it be, is taken in it" (p.71). Rolston takes an epistemological approach questioning "how we know what we know' when assessing the values in nature. For him, values themselves exist because of human responses to the surrounding world, so "world building does go on in the mind of the beholder" (p.74). Value, in a different way to other natural properties, lies absolutely in one's mind as part of a mental state, not an event in spacetime (ROLSTON, 1998), "yet the evolving mind is also controlled by the matter it seeks to investigate" (p.75).

Some values are taken commonsensical - which are not just the result of one's perception - are rooted in culture everywhere. People's understanding about nature 
evolved from experiencing nature as a utilitarian resource. Communal experiences, resulting from people interacting with nature, have set patterns for values on nature. Before the manifestation of ecology as a distinct discipline, landscape was perceived as a collection of live and inanimate objects, "a plurality of separate individuals" but such a notion has changed; ecology has revealed that nature is a complexity of articulations, and they together form an integrated biophysical unit (CALLICOTT, 1998: 57). Through the scientific lenses, culture and experiences together have produced the meanings of nature by praising it based on its "instrumental values" (VILKKA, 1997; ROLSTON, 1998).

According to Vilkka, "an instrumental-value view is the sufficient reasonable ground for nature conservation" (1997: 9), if it is taken into consideration the environmental services provided by standing forests (not stripped, deforested areas). For example, photosynthesis - following advances of science - gained new dimensions particularly in the face of deforestation, greenhouse effect(s) and global warming. From this perspective, the person understands that 'trees' have a function for human and nonhuman survival, and for this single reason, their existence has intrinsic value. Partridge (1998) challenges Rolston (1998) with his standpoint that nature has an objective value, and argues that "values" for nature are not aside from existing evaluators (p.81). Clearly, one must determine what is the worth and wonder of nature. There are important aspects raised about environmental ethics by questions such as, "what shall we do with regard to nature?" (SCHWEITZER, 1998: 86), which deals with issues of 'true morality' and nihilism, in a sense that 'sustainability' permeates all spheres of public decision; there has been a "fusion of politics and life in the modern world... a new form of power which Foucault calls biopower" (OJAKANGAS, 1997: 178). As a sole concept, Foucault (1982) explains power as the interventions of certain actions over the field of other possible actions. Nihilism and true morality are indeed an ontological discussion, and I do prefer to move to the question of 'what is ethics', which I consider more relevant at this stage.

Schweitzer (1998) explains that ethics consist "of practising the same reverence for life toward all will-to-live", as one does toward oneself (p.93); the human being is ethical when s/he helps all life which s/he is able to help, "and when s/he goes out of the way to avoid injuring anything living" (p. 94). Schweitzer (1998) provides further leads when he affirms that ethics is "responsibility with regard to everything that has life...ethics as self-devotion for the sake of life, motivated by reverence" (p.94). Taylor (1998) establishes environmental ethics as a life-centred system through which human beings are understood to be "no more intrinsically valuable than any other living thing but should see themselves as equal members of Earth's community" (p. 98), that is, human beings are "plain members and citizens of the biotic community" (LEOPOLD, 1998: 117).

There are always examples of these dualities and divides in our society. Maybe humans need a new enlightenment that would encourage different perceptions on how to get along with nature without killing it. Hence, maybe, it is time to break down old values and search for new ones, calling for the review of norms that are backed by the morals and ethics of the 60s. All these aspect reveal two different paradigms that pervade the society's views over the natural world: the biocentric and anthropocentric ones; two philosophical understandings on the values of the natural settings. These views can be 
identified as duelling ones, for example, in the disputes or ecological stalemates about deforesting a bush for new development areas.

That is, these paradigms are mostly antagonist forces in many aspects related to 'development' and 'preservation' (conservation, protection) of nature. Sustainable development was proposed by the Brundtland Commission Report, Our Common World, in 1987, as a way of harmonising the two contenders, competing forces. Protected areas are thus the most instrumental way of bringing a balance between different perceptions on nature. Protected areas add value to standing forests and to fairly preserved areas aiming at conserving them for future generations. The human presence and interventions on natural settings are regulated by law, so human impacts can be restricted and monitored. These areas are also the place for many recreational, leisure, adventure, and educational activities. That is, the type of development in protected areas should not result in 'environmental impacts' as those commonly observed in developmental zones. In terms of conservation and nature preservation, each category of protected area is abided by specific rules regulating any anthropogenic presence and interferences as specified in the IUCN. In a nutshell, national parks have had the mission of equalising the anthropocentric recreational demands with the biocentric conservationist ones. Jeffery (2005) points out that "environmental ethics is concerned with the issue of responsible personal conduct with respect to natural landscapes, resources, and species and non-human organisms" (p. $105)$, and the mere creation of parks makes clear the environmental ethics and concerns of humans towards nature. A standing forest holds multiple benefits, so they can be used for environmental interpretation and education to explain that humans are an offspring of the interacting forms of life on earth, part of an ecosystem, of a coevolution; humans a part of a "community of life" (HUGHES, 2001, p. 6). Visitors have a lot to learn about the existing wildlife and flora in the Parks, and about the connectedness of the ecosystems.

\section{Visitors and activities in the Parks: from contemplation, adventure, to environmental learning}

Parks usually accommodate an array of outdoor recreation and adventure activities from organized sports, such as mountain-biking, canoeing, rock climbing, abseiling, whitewater rafting to bushwalking, wildlife watching, and simply nature contemplation. Often parks are classified based on the types of activities they support, and their management system can have a holistic approach or a narrow one. Common categories of recreation areas are activity-oriented structured recreation with developed structures. Thus, Parks management can be anthropocentric oriented or resource-oriented. The latter has a biocentric perspective. The emphasis and priorities are 'conservation' and 'protection', and recreational developments are usually secondary at a managerial level (FRAWLEY, 1989; HU, 2002; LANKFORD, KNOWLES-LANKFORD, \& WHEELER, 2011; COCKS AND SIMPSON, 2015). The use of parks and other protected areas for educational activities and learning become a nexus for both anthropocentric and biocentric interests. The preserved areas become the main settings for environmental education and interpretation, exactly because of their existing ecological attributes and resources; otherwise they would be just another human-impacted area without tangible environmental and educational assets. 


\section{Environmental education and environmental interpretation: the interconnections}

Connect to nature programs are one of the straightforward attempt of rescuing and raising awareness about the intrinsic values of the natural world and how relevant the ecosystem is. As part of this process, environmental interpretation and education as well as educational recreation are essential tools to deliver successful ecological content. Environmental interpretation, educational games, recreation, and various plays in the outdoors provide the means to balance both anthropocentric and biocentric views of the surrounding natural world. Environmental education and environmental interpretation, what are the differences? Interpretation is an aspect of environmental education. The understanding on them varies with researchers perceiving both terms with commonalities and differences.

Environmental education has as a foundation a set of hierarchical learning principles elaborated in 1977 and is part of the Tbilisi Declaration. The principles consist of theoretical action-based models in environmental education (KNAPP, 1998). Conversely, environmental interpretation is grounded on the Tilden's six principles in the 1950s; the principles have their instructive relevance; however, the field has not developed strategic plans, guidelines - a road map - to succeed in promoting attitudinal change goals (KNAPP, 1998). Tilden (1977) defined interpretation as "an educational activity which aims to reveal meanings and relationships through the use of original objects by first-hand experience and by illustrative media, rather than simply to communicate factual information" (p. 8, 9). Ham (1992) explains that 'environmental interpretation' is the way that mediating educators find to translate "the technical language of a natural science" into clear, plain, explicit ideas and terms so the audience can readily understand the characteristics, features, functionalities, importance, interrelations of a biotic (living beings - plants and animals) and abiotic (nonliving components existing in the air, water, and land) elements in the environment (GORKE, 2003). Environmental interpretation is expected not to reproduce outdoors the dynamics and techniques as used indoors in a formal education. Environmental interpreters usually perform a blending role being 'educators' and 'entertainers' using analogies, similes, comparisons, metaphors, and storytelling to hold the attention and interest of an audience (HAM, 1992; WEILER AND BLACK, 2015), so they can successfully deliver the environmental messages and properly carry out the learning activities.

According to Knapp (1998), the notions of interpretation, environmental interpretation, nature interpretation, nature study and environmental education have intersections and commonalities. Even though they have common conceptual and approach aspects, environmental education and environmental interpretation are not taken as synonyms. Knapp (1998) observed three major differences which make them distinct to each other: i) environmental education is more linked to formal institutions and sequential learning attendance by the participants; it is a more structured content delivery. By its turn, ii) environmental interpretation is not usually connected to any program development aiming behaviour change the same way as environmental education pursues it; iii) another difference between the two terms is that environmental interpretation can increase the acquisition of ecological knowledge and of resource site information; it can raise awareness of participants, of visitors (WALBERG 
and WALBERG, 1994; KNAPP and BARRIE, 1995). Additionally, environmental interpretation is usually a short-term experience which makes difficult to find evidences it can create stewardship or preservationist postures as attitudinal changes (KNAPP, 1996). On the other hand, environmental education has produced more considerable signs it can impact on participants ' behaviour. What is the role of guiding in delivering environmental interpretation and education for enhancing the visitors' experience while contributing to conservation?

\section{The relevance of guiding for visitors`experience and conservation: a conceptual approach}

Guiding implies a multitude of ways for acquiring knowledge and learning about a visited destination. According to Weiler and Black (2015), more than 280 papers are related specifically to tour guides or tour guiding, and 91 percent have been published since 1990 (p.5). Within the tourism literature, terms used are 'tour guide', 'tourist guide', 'tour leader', 'tour manager', 'tour escort', and 'courier' (WEILER and BLACK, 2015 , p.2), and even 'tour conductor'. There is a sort of consensus among researchers about the instrumental (leadership) role of the guide to keep a tour running successfully for the visitors in terms of safety, logistics, and certainly as individuals in charge of the mediation and interpretation of content and sites, "this in turn has drawn attention to the importance of the communicative competency of guides, including the application of best practice principles in interpretation and intercultural communication" (WEILER and BLACK, 2015, p.2), which, are also elements of a successful tourism operation.

As explained by Beck and Cable (2002), interpretation is a communicational process which helps to interconnect the visitors to the [cultural, nature] resource [or place], it is visitor centered. For example, interpretation is habitually perceived as effective in terms of managing the interactional processes between 'visitors' and 'wildlife' because it can result in levels of environmental awareness with an augmented view of a conservation ethic (BECKMANN, 1991; MOSCARDO, 1998; HOWARD, 2000), and Orams (1996) emphatically states that interpretation [in guiding] is the most effective strategy for managing wildlife encounters. Interpretation should provoke visitors to reflect and to connect with cultural and natural elements of visited sites, to local people, culture, artefacts, and to historical events to the extent it can fill them with information which can lead to thoughtfulness about care and of stewardship (WEILER and BLACK, 2015, p. 18).

The tour guide is expected to be a skilled and knowledgeable person to escort groups of visitors in venues, places and sites of touristic interest such as natural areas, historic buildings, museums; thus, they are expected to offer interpretation of cultural and natural assets "in an inspiring and entertaining manner" (WEILER and BLACK, 2015, p.3). Mediation is thus critical for touching one's perception and feeling in regard to specific themes and topics in hosting places, particularly in terms of post-visit postures, "the strategic use of tour guides to influence on-site behaviour and change post-visit attitudes and behaviours might also be considered as mediation" (WEILER, 2015, p.35). However, Holloway (1981) and Cohen (1985) have noted more than 30 
years ago that the role of guides have not been properly valued; rather, as an occupation, being lamentably marginalized, overlooked in some cases, mostly in terms of pecuniary rewards, , particularly in developing countries. Tour guiding commonly demands eclectically skill, abilities and training in introducing and mediating culture, places, ecosystems, landscapes, and local people attributes.

Concerned with the role of guides and the benefits and enhancement they could provide for visitors, local stakeholders, and destination sites, Cohen (1985) presented two conceptual spheres with course of action for the guides: tour management in which guides have an instrumental (leadership) role in organizing and managing group(s); and the experience management in which guides have as a role to facilitate visitors' engagement and learning (mediation) (Refer to Table 1.0). In 1993, Weiler and Davis advanced the discussion by adding a third sphere to Cohen's model with a focus on the role of the guide in destination/resource management. Cohen's (1985) and Weiler and Davis`s (1993) "conceptual frameworks have stood the test of time in drawing attention to both the diversity of guiding roles that are common to all contexts and types of tour guiding, and the specialist roles that ecotour/nature guides are required to perform" (p. 25).

By taking into account the three spheres, a framework is proposed in this paper aiming to examine the roles of guides and the relevance of guiding, that is, instrumental (tour management), mediatory (experience management), and interpretive (resource management) (Table 2.0). In regard to 'resource management' it can refer to both cultural/heritage and natural resources. Guides can use interpretation or mediation to explain or connect visitors to some aspects of an Indigenous community, or, Indigenous lifestyle and traditional knowledge.

Table 2.0 - The three key spheres of tour guiding and the roles of a contemporary tour guide

\begin{tabular}{l|l}
\hline $\begin{array}{l}\text { Sphere 1: Tour } \\
\text { management }\end{array}$ & $\begin{array}{l}\text { Instrumental (leadership) roles focused on organizing and managing the } \\
\text { group }\end{array}$ \\
\hline $\begin{array}{l}\text { Sphere 2: Experience } \\
\text { management }\end{array}$ & Mediatory roles focused on facilitating individual's engagement and learning \\
\hline $\begin{array}{l}\text { Sphere 3: Destination/ } \\
\text { Resource management }\end{array}$ & $\begin{array}{l}\text { Interpretive and role-modelling roles focused on the sustainability of host } \\
\text { environments, communities and destinations. }\end{array}$ \\
\hline
\end{tabular}

Source: Weiler and Black (2015, p. 28) - Cohen`s (1985) Framework adapted.

Within the perspective of these three spheres, guides can add value to a visitor experience and to a local site, or destination, contributing to the conservation process. That is, "nature-based tour guides also encourage participants to reduce their impacts onsite, and they facilitate a change in values towards long-term conservation" (WEILER and 
BLACK, 2015). The guides can also introduce outsiders to a specific culture providing specific information, raising awareness of and respect for Indigenous peoples. As an example, bush tucker or a wildlife encounter guided (led and mediated) by Indigenous people can be a fascinating experience in getting to know about a local forested area by using the senses. The three key spheres can be used to analyse tour guides, guided tours, and tourism operations at a local and regional level.

Jennings and Weiler (2006) explain that tour guides can mediate a visitors' connection to localities and local issues to the extent that they can enhance or detract them from their experience, either facilitating or inhibiting outcomes, because the guides perform both an instrumental and mediatory role. Weiler and Black (2015) provide four domains in a framework to examine the mediatory role of tour guides, and they make a distinction between mediation and interpretation, in that 'interpretation' is a role in itself with a collection of techniques necessary for mediation by using interpretive strategies such as analogies, anecdotes, narratives, storytelling, metaphors, and even non-verbal communication such as artefacts and experiencing through the senses (touching, listening, tasting, smelling, seeing) (COHEN, 1985; MOSCARDO, 1998; COLQUHOUN, 2005; JENNINGS and WEILER, 2006; WEILER and DAVIS, 1993).

Put simply, there is no mediation without interpretation, because the techniques used in the interpretation can help "visitors to understand and feel empathy towards objects, persons, sites or environments" (WEILER and BLACK, 2015, p.35), it is the guide's role to get the visitors "under the skin of visited destinations" (MCGRATH 2007, p. 376), and the mediation role is all-encompassing on enhancing a visitor's experience as pointed out by Weiler and Black (2015): mediating/brokering physical access; mediating/ brokering encounters (interactions); mediating/ brokering understanding (intellectual access); and mediating/brokering empathy (emotional access).

In order to satisfactorily act as a guide, a set of competences are necessary in guiding, particularly in dealing with heterogeneous, multicultural visitors. Such competences are: fluency in the visitors' language; a local culturally knowledgeable person; social-interpersonal skills; expression and demonstration of cultural pride; discernment in what is culturally suitable to share; and engaging in two-way communication (WEILER and BLACK, 2015, p.65).

In regard to the role of guides and natural resource management, the cases examined in the literature reveal that the guides face restrictions in achieving wideranging conservation outcomes. Most of their roles in terms of nature management rest on reducing on-site impacts by delivering 'conservation messages' to visitors while putting emphasis on their conduct at the moment of having contact with natural assets either a forest or a reef.

The guides can play an interventionist role in guiding visitors on the trails by working with them in order to avoid excessive noise, off-track walks, collection or removal of natural elements, including those of cultural value such as sacred rocks, petrified wood, etc. (WIDNER and ROGGENBUCK, 2000; LITTLEFAIR and BUCKLEY, 2008), and certainly "guided tours and roving interpretation rangers [can]... convey important conservation messages to visitors, helping them to enjoy, connect with 
and value our significant and special places" (Colquhoun, 2005, p. 7). Guides, as well as rangers, and a series of tour educators can play a pivotal role in introducing and connecting visitors to nature and wildlife in natural settings, such as Parks and bush areas (see Fig. 2, 3, and 4).

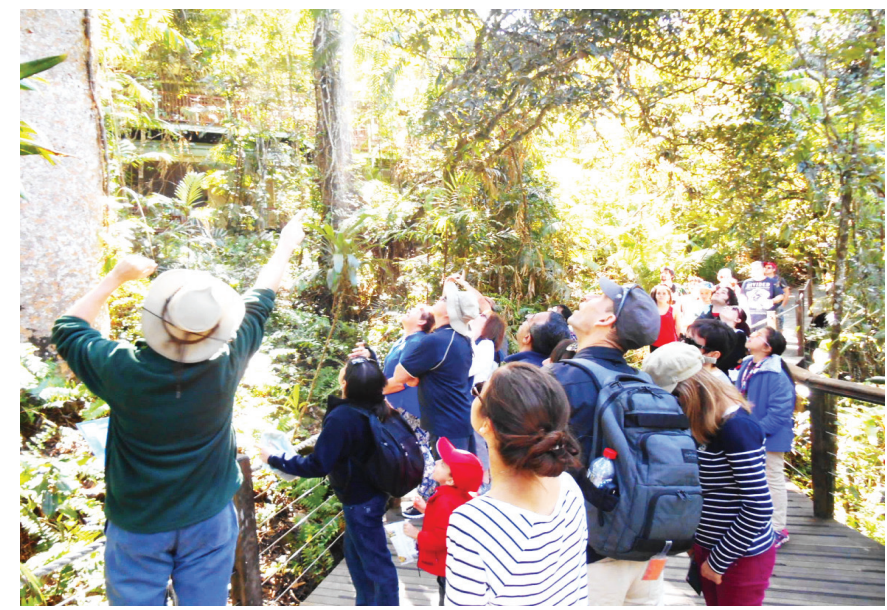

Figure 2. A ranger provides environmental interpretation to visitors in the Skyrail Rainforest near Kuranda, in Cairns, Queensland, Australia Source: Ismar Lima, fieldwork in Queensland, Australia, 2015 and 2016.

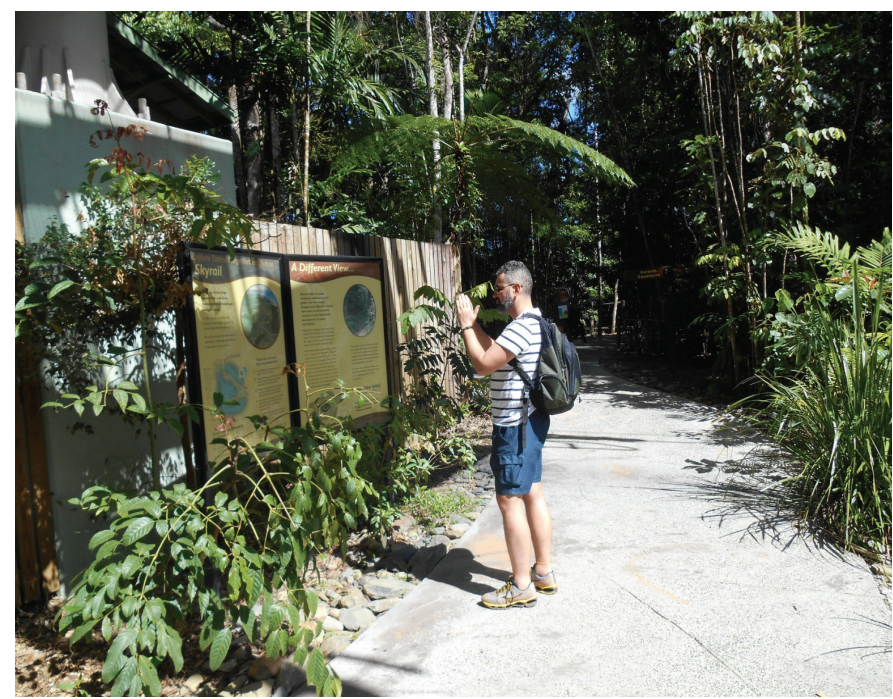

Figure 3. A visitor reads and takes pictures of environmental educational signs in the Skyrail Rainforest near Kuranda, in Cairns, Queensland, Australia. Source: Ismar Lima, fieldwork in Queensland, Australia, 2015 and 2016. 


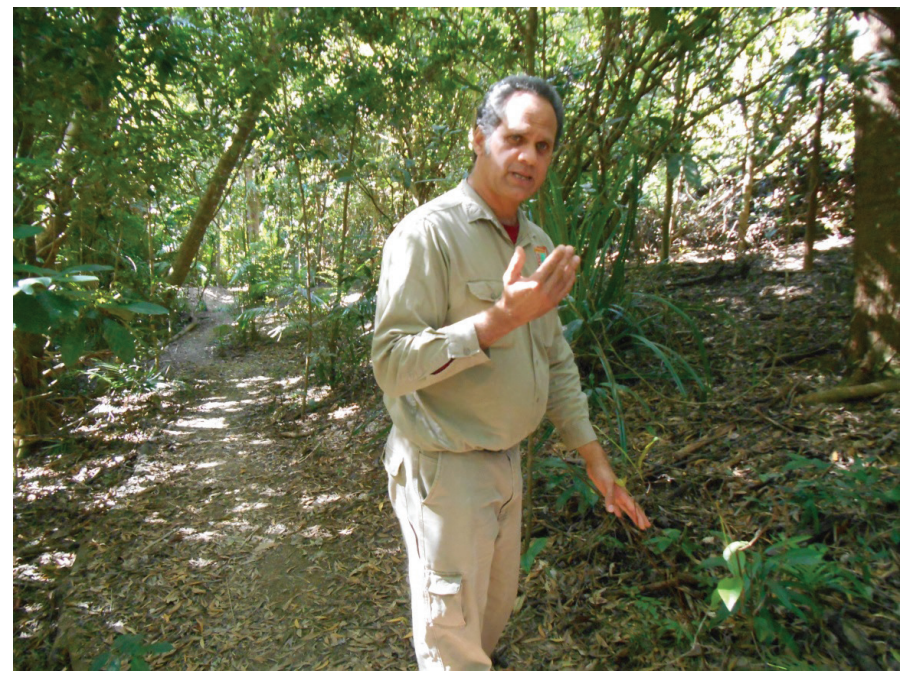

Figure 4. An Aboriginal ranger explains the values of the plants in a highly integrated ecosystem in the Skyrail Rainforest near Kuranda, in Cairns, Queensland, Australia.

Source: Ismar Lima, fieldwork in Queensland, Australia, 2015 and 2016.

Zeppel \& Muloin (2008) found that visitors who are exposed to environmental messages are reported to have higher levels of pro-conservation behaviour, and are more environmentally cognizant. Some evidence shows that a tour guide who makes himself/ herself authoritatively respected can lead visitors into more responsible behaviour during their stay in natural areas (LITTLEFAIR, 2004). Table 3.0 provides an outline of the main sustainability outcomes and how tour guiding can help to achieve them. The list includes the enhancement of the visitors ' understanding and valuing of communities, cultures and environments, as well as purposeful actions aiming at influencing visitors behaviour en route and at destinations. These contributions to sustainability outcomes can be achieved through Indigenous tourism operations, particularly because of their traditional values, tenets, beliefs, and lifestyles, which strongly connect them to nature and landscapes.

Table 3.0 - Possible Tour Guiding Contributions to Sustainability Outcomes

\begin{tabular}{l|l}
\hline $\begin{array}{l}\text { A Selection of Sustainability } \\
\text { Outcomes }\end{array}$ & $\begin{array}{l}\text { How tour guiding can contribute to meeting sustainability } \\
\text { outcomes }\end{array}$ \\
\hline $\begin{array}{l}\text { Improved understanding of natural } \\
\text { and cultural values }\end{array}$ & $\begin{array}{l}\text { Enhancing visitors` understanding and valuing of communities, } \\
\text { cultures and environments }\end{array}$ \\
\hline $\begin{array}{l}\text { Increased economic prosperity of } \\
\text { local businesses and communities }\end{array}$ & \\
\hline $\begin{array}{l}\text { Increased social benefits to/ } \\
\text { engagement of local communities }\end{array}$ & Influencing visitors` behaviour en route and at destinations \\
\cline { 1 - 1 } $\begin{array}{l}\text { Reduced production and } \\
\text { responsible disposal of waste }\end{array}$ & \\
\hline Reduced use of water and energy & \\
\hline
\end{tabular}




\begin{tabular}{l|l}
\hline $\begin{array}{l}\text { Protected/improved quality of } \\
\text { environmental conditions (e.g. } \\
\text { water, soil, air quality) }\end{array}$ & $\begin{array}{l}\text {-Influencing and monitoring visitors` behaviour en route and at } \\
\text { destinations } \\
\text {-Fostering visitors` post-visit attitudes and behaviours }\end{array}$ \\
\hline $\begin{array}{l}\text { Protected/improved biodiversity } \\
\text { conservation of the destination }\end{array}$ & $\begin{array}{l}\text {-Enhancing visitors` understanding and valuing of communities, } \\
\text { cultures and environments. } \\
\text {-Influencing and monitoring visitors` behaviour en route and at } \\
\text { destinations } \\
\text {-Freater respect for/enhancement of } \\
\text { culture, Heritage and/or traditions }\end{array}$ \\
\hline
\end{tabular}

Source: Weiler \& Black, 2015, p.73, adapted from Choi and Sirakaya (2006), Moore et al. (2009), Tonge et al. (2005) and WTTC (1996).

\section{Potential visitors' choices for enjoying the Parks in Queensland: from outdoor adventures to eco-educational activities}

There are many ways a local, interstate, or international visitor can enjoy and experience parks and natural settings in Queensland. The activities and facilities differ from park to park. Some activities usually practiced outdoors in Parks, reserves, beaches, etc. in Queensland include water-based, land-based, and air-based adventure/ recreational ones. Adventure/Recreational activities: body boarding; abseiling; bushwalking; camping; canoeing and kayaking; cave tour; cycling; fishing; fossicking; four-wheel driving; hiking; horse riding; kite-surf; mountain biking; parasailing; reef activities; rock climbing; trail-bike riding; rock climbing; whitewater rafting; skydiving; stand-up paddle; surf; etc. Educational and nature observation activities: wildlife encounters/Watching (whales, turtles, bats, birds); guided tours; and 'Connect with Nature, usually ranger-managed activities. In Queensland, there are some regular guided tours conducted by QPWS rangers: Mon Repos (seasonal marine turtle nesting and hatching); Chillagoe-Mungana Caves (spectacular limestone caves); Mt Etna Caves (seasonal bat viewing); Fort Lytton and St Helena Island National Parks (cultural history tours); and David Fleay Wildlife Park with daily wildlife presentations, guided walks, and ecological talks and showcases.

Table 4 outlines the main features, characteristics, and attractions of Springbrook National Park, one of the five National Parks on Gold Coast region. The Table 4 helps to illustrate the main natural and heritage resources of that Park, as well as it summarises the major educational activities, the existing learning resources, tools, and the content delivery system adopted by the managers and rangers at Springbrook. The Park has 6,725 hectares and it is part of the Gondwana Rainforests of Australia World Heritage, and has waterfalls, cascades, shallow swimming pools, and creeks as key features (Gold Coast Council, 2013). It has many lookout platforms, tracks, and trails ranging from 30 meters up to 17 kilometres with distinct levels of physical difficulties.

Springbrook National Park provides the visitors with opportunities for: camping, bushwalking, guided tours, picnic and day-use areas, wildlife viewing, and horse riding, and nature contemplation and recreational time. Bushwalking, guided walks and tours, and wildlife watching are some of the activities which propitiate a visitors ' contact with the natural assets and resources in the Springbrook. The Park is one of the natural settings used for educational and recreational activities in the Connect with Nature Program. 
Environmental interpretation is offered and managed by both accredited tour operators and by the rangers (refer to Table 4).

Table 4. An outline of the main features, attractions, natural resources, and educational and recreational activities in the Springbrook National Park on Gold Gold, Queensland, Australia.

\section{SPRINGBROOK NATIONAL PARK}

\section{Park key features \& Main attractions}

- The Park is situated about $100 \mathrm{~km}$ south of Brisbane and encompasses four major sections on its plateau: Springbrook section; Mount Cougal; Natural Bridge; and, Numinbah section.

- The Park has 6,725 ha. and it is part of the Gondwana Rainforests of Australia World Heritage, and has waterfalls, cascades, shallow swimming pools, and creeks as key features.

- It has many platform lookouts, tracks, and trails from 30 meters up to 17 kilometres with distinct levels of difficulties.

- John Stacey Suspension Bridge across Little Nerang Creek.

- The Park provides the visitors with opportunities for: camping, bushwalking, guided tours, picnic and day-use areas, wildlife viewing, and horse riding. Nature contemplation and recreational time.

- The Queensland Parks and Wildlife Service (QPWS) manages the Springbrook National Park under the Nature Conservation Act 1992 and Austinville forest reserve trails under the Forestry Act 1959. Park management is to preserve the natural and cultural values with long-term benefits.
Key educational activities \& possibilities

- Bushwalking

- Guided walks

- Wildlife viewing

- Nature contemplation

- Connect with Nature Program: Lyrebird Walk for spotting the rainforest dwellers.

- Subtropical rainforest, ancient Antarctic beech, hoop pines, eucalypt forest and montane heath, canopy, vines, palms, epiphytes and large trees known as strangler figs house a fantastic variation of wildlife.

- More than 100 bird species live in the park.

- Mammals living in the park: pademelons, small rainforest wallabies. Reptiles: glossy black skinks known as land mullets, and snakes such as the sleepy carpet pythons. There is a diverse selection of water-dwelling animals. Frogs are the most noticeable, blue spiny crayfish, and eels. Platypus, the Richmond birdwing butterfly, and Koalas can also be spotted in the Park.
Learning resources, tools, delivery System

- The Park is one of the natural settings for delivering activities of the Connect with Nature Program

- Environmental interpretation by tour operators and by rangers.

Source: Ismar Lima, 2015, with information from various online sources such as QPWS, Gold Coast City Council, and the Department of National Parks, Sport, and Racing. 


\section{Environmental learning and educational recreation connecting visitors to nature on Gold Coast}

This Section specifically deals with the two main educational programs offered in protected areas of Gold Coast: Connect with Nature and NaturallyGC. These programs usually address environmental and ecological content to school groups; some of the educational activities and environmental interpretation aim to fill state disciplinary demands what makes their visit a curriculum-based experience. The Connect with Nature Program is designed and managed to facilitate the contact between 'individuals' and 'nature', and it enables a full contemplation of the Queensland's natural and cultural heritage.

The Program has activities that encourage learning, appreciation and a structured disciplinary understanding of natural areas. It is designed to engage children and adults, mostly in groups, with activities that promote levels of interactivity with nature and wildlife. Park rangers, specialised in educational content delivery and interpretation, guide the visitors so they can learn and discover the functionalities, characteristics, and peculiarities of the natural world. Connect with Nature Program is all-encompassing in terms of participants; it includes school groups the year long, even during school holidays. Some of the activities are related to special event dates and school curriculum content. 'Connect with Nature' facilitates the following activities and experiences: spotlighting the nocturnal creatures of Queensland's parks and forests; guided walks; wildlife encounters; children's activities; slideshows; stage shows; theatre performances.

The Gold Coast has been a place for the NaturallyGC program which is designed for people interested in getting involved in activities which can make them more connected to the city's natural environment. It is an educational and recreational program with a great variety of free or low cost activities which take place across Gold Coast, particularly in its parks and green areas. The city is regarded by the Council as one of the greenest cities in Australia with strong commitment to preservation. It has 20,000 hectares of parks and recreational public areas with can be a special arena - a site - for environmental education, educational recreational, nature enjoyment and outdoor plays for young people, adults, and families. According to Tom Tate, Gold Coast Mayor, "the city acknowledges that the health of our natural areas has a profound effect on the quality of our lifestyle and the state of our economy. We are custodians of a pristine natural environment and the City takes this responsibility very seriously" (NaturallyGC 2015-16 Report, Preface).

The NaturallyGC runs a variety of environmental education workshops and activities which include: outdoor nature and education activities for kids; community planting and landcare projects; bush tucker; guided bushwalks; live animal displays; live reptile shows; managing pest animals; native bees; native gardening and plant propagation; nature photography nature photography competition; platypus watch; trail running, etc. Table 5 shows some of the main activities, frequency, and time they are offered, as well as costs or fees involved. 
Table 5 - NaturallyGC Program managed by Gold Coast Council

\begin{tabular}{|c|c|c|}
\hline Date & NaturallyGC Activities & Costs \\
\hline \multicolumn{3}{|l|}{ Workshops } \\
\hline Multiple & Waterwatch & free \\
\hline Year round & Nature Play QLD 8 hour screen free challenge & free \\
\hline \multirow[t]{2}{*}{ Year round } & Nature Play QLD Passport to an Amazing Childhood Program & free \\
\hline & Guided bushwalking and running & \\
\hline 14 August & Guided bushwalk - Coombabah & free \\
\hline 06 October & Guided bushwalk - Elanora Wetlands & free \\
\hline Multiple & Guided bushwalk - Springbrook & free \\
\hline Multiple & Club Kokoda Gold Coast bushwalking & $\$ 2.00$ \\
\hline Multiple & Responsible Runners Gold Coast & free \\
\hline Multiple & Gold Coast Trail Running Series & free \\
\hline \multirow[t]{2}{*}{ Year round } & Gold Coast Trail Runners & free \\
\hline & Explore our parks & \\
\hline Year round & $\begin{array}{l}\text { Eagle heights downhill mountain } \\
\text { bike trail }\end{array}$ & free \\
\hline Year round & Nature walk - Berree Badalla and Tarrabora Reserve & free \\
\hline Year round & Nature walk - Coombabah Lakelands Conservation Area & free \\
\hline \multirow[t]{2}{*}{ Year round } & $\begin{array}{l}\text { Horse riding and walking trails - Crystal Creek Reserve/Ruffels Road } \\
\text { Reserve, Willowvale }\end{array}$ & free \\
\hline & Volunteer activities and partnerships & \\
\hline 5 September & $\begin{array}{l}\text { National threatened species day } \\
\text { Koala tree planting }\end{array}$ & free \\
\hline 23 September & Junior Landcare planting day & free \\
\hline 6 March & Community creek clean-up day & free \\
\hline Feb-Nov & Beaches to bushland & free \\
\hline Feb-Nov & BeachCare & free \\
\hline Sep-Apr & Community Planting Program & free \\
\hline Multiple & Platypus Watch & free \\
\hline
\end{tabular}

Source: This table is based on the information in the NaturallyGC Report Online. At http://www.goldcoast. qld.gov.au/documents/bf/naturallygc-program.pdf

\section{Final considerations and remarks on Queensland Parks, Conservation, and Visitors`Experiences}

Although some evidences produced by this literature review are not entirely new, it is of attention the role of tour guides and Park rangers in mediating the connection between visitors and nature; they have had an important mediatory role for the visitors in wildlife and nature encounters. Landscapes, ecosystem, traditional knowledge, world views, and various cultural and heritage assets have been the object of 'mediation' by the guides and rangers. Through a mediatory role, visitors can become even more aware of the values and importance of nature leading them to an increased recognition of the need of sustainable practices in the human-nature relations. 
In the literature, the role of park rangers for visitors' environmental learning and awareness raising is still scarce. Research shows this field is somewhat neglected, not fully developed, demanding a more comprehensive investigation, particularly on the need of including educational activities and pro-conservationist messages as part of the visitors`experiences. While most visitors do not visit to learn about conservation per se, it is clear that many seek to improve their knowledge about the natural and cultural values of an area (BEAUMONT, 1999). The question of how to conserve and protect the natural resource while promoting available educational and recreational opportunities is among the greatest challenges faced by many protected area agencies (PARKIN, 2006, p. 45). At an Institutional level, it seems there is an effort by the government agencies to carry out educational activities, albeit with an emphasis on 'visitor education' for conservationist goals. Efforts also have been done to create effective instruments to manage the Parks, including monitoring strategies. Critical for guaranteeing visitors` enhanced experiences is the healthy state and the good quality of the Parks which can be achieved through management plan. Notwithstanding, Howard (2013) underlines the extreme relevance of the role of rangers in visitor management and education.

As for the research question, are the National Parks serving as natural settings for environmental interpretation and education of the visitors in Queensland? The combination of different concepts of Parks in Queensland has rewarded the visitors with great opportunities for environmental learning, wildlife encounters, and nature contemplation, particularly the young school visitors engaged in curriculum-based learning, and those who have participated in the Connect with Nature and NaturallyGC Programs. This case study reveals that educational activities can be largely expanded to accommodate in great number general visitors. In order for it to happen, more efforts should be done to carry out 'educational and recreational activities' on a regular basis in the Parks, making them a further attraction and environmental learning tool. In this sense, some challenges have been identified and need to be overcome such as the high workloads of rangers and of managers who split their time and efforts in promoting conservation and maintenance of the Parks. Other identified issues were the lack of proper marketing and of alluring park websites. In addition to that, specific financial allocations for new educational programs and for strengthening the existing ones should be of great attention in a park management.

\section{Acknowledgment}

This paper is part of a broad postdoctoral research project dealing with the 'environmental and cultural learning in tourism development in parks' in Australia, and it received financial support from the Brazilian Higher Education and Research Agency, CAPES, process number 99999.006809/201406, Call: Portaria 36/2013 Estágio Pósdoutoral - Chamada I 2015 also with Institutional support from Universidade Estadual de Roraima, UERR, in Brazil, and the School of Business and Tourism, at Southern Cross University, SCU. My thanks also goes to prof. Dr. Betty Weiler, my collaborating professor at SCU, and Dr. Arianne Reis, SCU, Jeremy Novak, Jun Xu, Simon Wilde, Silvia Nelson, for their academic support. The International Foundation for Science, Nature, and Tourism in Latin America and Iberian Peninsula, RECINATUR Intl. and the 
MULTIAMAZON Lab have been largely supportive to my research projects in Australia and in Brazil.

\section{References}

ARMSTRONG, E. Kate; WEILER, Betty. (2003). Improving the tourist experience: evaluation of interpretation components of guided tours in national parks. Sustainable Tourism CRC, Gold, 57 pages.

BEAUMONT, Narelle Kay. Ecotourism: The contribution of educational nature experiences to Environmental Knowledge, Attitudes and Behaviours. Unpublished PhD thesis, Griffith University, Brisbane, 1999.

BECK, Larry; CABLE, Ted. T. Interpretation for the $21^{\text {st }}$ Century: Fifteen guiding principles for interpreting nature and culture. Urbana, Illinois, USA: Sagamore Publishing, 2002, 204 p.

BECKMANN, Elizabeth. A. Environmental interpretation for education and management in Australian National Parks and other Protected Areas. Unpublished Ph.D. thesis, University of New England, NSW, 1991.

BOLWELL, J. An overview of interpretation in National Parks Agencies in Australia. Unpublished Master's dissertation in Applied Science. School of Environmental and Information Sciences. Charles Stuart University, 1996.

CALLICOTT, J. Baird. Animal liberation: A triangular affair. In: POJMAN, Paul; POJMAN, Louis P. (Eds.), Environmental Ethics: Readings in Theory and Application. Belmont, USA: Wadsworth Publishing Company, 1998, p. 29-59.

COCKS, S; SIMPSON, S. Anthropocentric and ecocentric: an application of environmental philosophy to outdoor recreation and environmental education. Journal of Experiential Education, v. 38, n.3, p. 216-227, 2015.

COHEN, Erik. The tourist guide: the origins, structure and dynamics of a role. Annals of Tourism Research, v. 12, n.1, p. 5-29, 1985.

COLQUHOUN, Fiona. Interpretation handbook and standard - Distilling the essence, Department of Conservation, Wellington, New Zealand, 2005.

DEPARTMENT OF ENVIRONMENT, DOC. Benchmarking and best practice program: user pays revenue, prepared for ANZECC. Working Group on National Parks and Protected Areas Management, Department of Environment, Queensland, 1996.

DEPARTMENT OF THE ENVIRONMENT, AUSTRALIAN GOVERNMENT. Available online at, https://www.environment.gov.au/ Accessed on 22.12.2015.

DEPARTMENT OF NATURAL RESOURCES AND ENVIRONMENT VICTORIA. Best practice in Park interpretation and education: a Report to the ANZECC. Working Group on National Park and Protected Area Management, Department of Environment and Heritage, 1999, 88 pages. 
FRAWLEY, K. J. Cultural landscapes and national parks: Philosophical and planning issues. Australian Parks and Recreation, v. 25, n.3, p. 16-23, 1989.

GERLACH, Anne-Marie (Ed.). Essential Geography for Queensland 2. South Yarra, Australia: Macmillan Education Australia Pty Ltd, 2008.

GOLD COAST COUNCIL. Springbrook National Park. Feasibility Study for Sprinbrook Gateway Tourist Information. Final Report. Prepared by Clouston Associates. Economic and tourism committee Meeting 18 July 2013. Available online at, http://www.goldcoast.qld.gov.au/documents/ma/economic-20180718-attachment Item_1.pdf. Accessed on 28.12.2015.

GORKE, M. Our planet's species: a challenge to ecology and ethics. Washington, DC., USA: Island Press, 2003, p. 410 pages.

HAM, Sam. H. (1992). Environmental interpretation: a practical guide for people with big ideas and small budgets. University of Idaho, USA.

HOWARD, J. L. Managing the natural environment: the role of park rangers and the skills they need. Rural Society, v. 22, n.3, p. 242-250, 2013.

. Research in progress: Does environmental interpretation influence behaviour through knowledge or affect? Australian Journal of Environmental Education, 15/16, p. 153-156, 2000.

HUGHES, J. Donald. An environmental history of the world. Humankind's changing role in the community of life. London, UK: Routledge, 2001, 264 pages.

HUGHES, M.; MORRISON-SAUNDERS, A. Interpretation, activity participation, and environmental attitudes of visitors to Penguin Island, Western Australia. Society and Natural Resources, n. 18, p. 611-624, 2005.

HU, W., WALL, G. Interpretive guiding and sustainable development: A framework". Tourism Management Perspectives, n. 4, p. 80-85, 2012.

IUCN. Guidelines for Protected Area Management Categories. IUCN, Gland, Switzerland and Cambridge, UK, 1994.

JEFFERY, Michael I. Environmental Ethics and Sustainable Development: Ethical and Human Rights Issues in Implementing Indigenous Rights [online]. Macquarie Journal of International and Comparative Environmental Law, v. 2, n. 1, p. 105-120, 2005. Available at, http://search.informit.com.au/documentSummary; $\mathrm{dn}=356410881440015 ; \mathrm{r}$ es=IELHSS. Accessed on 28.12.2015.

JENNINGS, Gayle Routh; WEILER, Betty. Mediating meaning: Perspectives on brokering quality tourism experiences. In: G.R. JENNINGS, Gayle Routh and NICKERSON, N. P. (Eds.) Quality tourism experiences. Burlington, MA, Elsevier Butterworth-Heinemann, 2006, p. 57-78.

KERN, Christine Luise (2006). Demarketing as a tool for managing visitor demand in national parks - An Australian case study. Unpublished Master`s dissertation. University of Canberra, Australian Capital Territory, Australia, August 2006, 167 pages. 
KNAPP, Doug; BARRIE, Elizabeth. Should we interpret issues or ecology? The Interpretive Sourcebook. THE PROCEEDINGS OF THE 1995 NATIONAL INTERPRETERS' WORKSHOP. Madison, WI, USA: Omnipress, 1995, p. 330-345.

KNAPP, Doug. Evaluating the impact of environmental interpretation: A review of three research studies. COALITION FOR EDUCATION IN THE OUTDOORS: THIRD RESEARCH SYMPOSIUM PROCEEDINGS. Cortland, NY, USA: Coalition for Education in the Outdoors, 1996, 127-136.

Applied interpretation: putting research into practice. Fort Collins, Colorado, USA, InterpPress, 2008, 162 pages.

LANKFORD, Sammuel V.; KNOWLES-LANKFORD, Jill.; WHEELER, Daniel. A. An Introduction to Park Management. Urbana, Illinois, USA, Sagamore Publishing LLC, 2011.

LEOPOLD, Aldo. Ecocentrism: The land ethic. In: POJMAN, Paul; POJMAN, Louis P. (Eds.), Environmental Ethics: Readings in Theory and Application. Belmont, USA: Wadsworth Publishing Company, 1998, p. 222-231.

LITTELAIR, C. J. The effectiveness of interpretation in reducing the impacts of visitors in national parks. Unpublished $\mathrm{PhD}$ thesis, Griffith University, Brisbane, 2004.

LITTLEFAIR, C. J.; R. BUCKLEY, R. Interpretation reduces ecological impacts of visitors to World Heritage Site. Ambio, v. 37, n. 5, 338-341, 2008.

MADIN, E.; FENTON, D. Environmental interpretation in the Great Barrier Reef Marine Park, Journal of Sustainable Tourism, v. 12, n.2, p. 121-137, 2004.

MCGRATH, Gemma. Towards developing tour guides as interpreters of cultural heritage: The case of Cusco, Peru. In: Black, R. and Crabtree, A. (Eds.) Quality Assurance and Certification in Ecotourism. Wallingford, UK: CAB International, 2007, p. 364-394.

MOSCARDO, Gianna. Interpretation and sustainable tourism: Functions, examples and principles, Journal of Tourism Studies, v. 9, n.1, p. 2-13, 1998.

(2002). Don't know, don't care: the importance of information for visitors to the Great Barrier Reef. In: LAWS, Eric (Ed.). Tourism Marketing: quality and service management perspectives. Continuum, London, UK, pp. 159-168.

OJAKANGAS, Mika. The ethics of singularity in an era of complete nihilism. In:

O'Farrell, Clare. (Ed.), Foucault: The Legacy. Kelvin Grove, Queensland, Australia: Queensland University of Technology, 1997.

ORAMS, M. B. Using interpretation to manage nature-base tourism. Journal of Sustainable Tourism, vol. 4, n. 2, 81-94, 1996.

PARKIN, Danny Robert. Policy, Culture and the Achievement of Visitor Education Outcomes: a Case Study of the Queensland Parks and Wildlife Service. A doctoral 
thesis. School of Education and Professional Studies, Griffith University, 2006, 243 pages.

QPWS. Queensland Parks and Wildlife Service. Interpretive Manual, internal document, Qld National Parks and Wildlife Service, Brisbane, Qld, Australia, 1983.

QPWS. Queensland Parks and Wildlife Service. Interpretation and Education Strategy 2000 - 2002, internal document, Queensland Parks and Wildlife Service, Brisbane, Qld, Australia, 2000.

QPWS. Queensland Parks and Wildlife Service. Interpretive Planning Handbook, internal document, Queensland Parks and Wildlife Service, Brisbane, Qld, Australia, 2001.

ROLSTON, Homes. Does nature have intrinsic value? In: POJMAN, Paul; POJMAN, Louis P. (Eds.), Environmental Ethics: Readings in Theory and Application. Belmont, USA: Wadsworth Publishing Company, 1998, p. 105-118.

SCHWEITZER, Albert. Reverence for life. In: POJMAN, Paul; POJMAN, Louis P. (Eds.), Environmental Ethics: Readings in Theory and Application. Belmont, USA: Wadsworth Publishing Company, 1998, p. 198-204.

TAYLOR, Paul. Human-centered and Life-centered Systems of Environmental Ethics. In: POJMAN, Paul; POJMAN, Louis P. (Eds.), Environmental Ethics: Readings in Theory and Application. Belmont, USA: Wadsworth Publishing Company, 1998, p. 205-221.

TTF. Conceptualising the value of protected areas. A literature review of the value, financing and tourism potential of Australia`s protected areas. Tourism \& Transport Forum, TTF. Victoria University, 2013. Available online at, http:/www.ttf.org.au/ DisplayFile.aspx?FileID=2148. Accessed on 05.12.2015.

VICTORIA PARKS. Types of Park. Available online at, http://parkweb.vic.gov.au/ learn/information-for-students/managing-our-parks/types-of-parks. Accessed on 27.12.2015.

VILKKA, L. The Intrinsic Value of Nature. Amsterdam: Rodopi Editions, 1997.

WALBERG, H. J.; WALBERG, H. J., III. Losing local control. Educational Researcher, 23, 19-26, 1994.

WEILER, Betty. From memorable to meaningful: tour guiding as a tool for sustainable tourism. THIRD INTERNATIONAL RESEARCH FORUM ON GUIDED TOURISM. Conference proceedings, 4 - 6 April 2013, The Netherlands, 2013, p.14-26.

WEILER, Betty; BLACK, Rosemary. Tourism guiding research: insights, issues, and implications. Aspects of Tourism. North York, Ontario, Canada: Channel View Publication, 2015.

WEILER, Betty; HAM, S. H. (2001). Tour guides and interpretation. In: Weaver, D. (Ed.) Encyclopaedia of Ecotourism. Wallingford: CABI Publishing, 2001, p. 549-563. 
WEILER, Betty; YU, X. Dimensions of cultural mediation in guiding Chinese tour groups: Implications for interpretation. Tourism Recreation Research, v. 32, n.3, p. 13-22, 2007.

WIDNER, C. J., ROGGENBUCK, J. Reducing theft of petrified wood at Petrified forest national park. Journal of Interpretation Research, v. 5, n.1, p.1-18, 2000.

ZEPPEL, Heather, MULOIN, S. Conservation benefits of interpretation on marine wildlife tours. Human Dimensions of Wildlife 13, p.280-294, 2008.

ISMAR Borges DE Lima

Postdoc Studies at the School of Tourism and Business, Southern Cross University, SCU, Australia; PhD holder in Geography and Tourism by the Waikato University, New Zealand; Master's Degree in International Relations by the International University of Japan, IUJ. Currently, Dr. Lima is a permanent professor at State University of Roraima, UERR, Brazil, and Adjunct Lecturer at SCU, Australia. He is an active member of the MultiAmazon Lab and RECINATUR Foundation for Science, Nature, and Tourism. Physical Address: UERR, Rua 7 de Setembro, 231, Boa Vista, Roraima, Brazil. Cep: 69306-530

E-mail: ismarlima@yahoo.com.br

Recebido para publicação em agosto de 2015 Aprovado para publicação em novembro de 2015 